\title{
THE IMPACT OF SOCIAL INTERNET PRACTICES ON THE PSYCHOLOGICAL WELL-BEING OF SENIOR PUPILS
}

https://doi.org/10.37096/SHDISJ-20-2.2-0009

ORCID ID: 0000-0003-3021-4547

Naydonova Lyubov

ORCID ID: 0000-0002-1222-295X

\begin{abstract}
The article deals with the study of the peculiarities of the impact of social Internet practices on the psychological well-being of senior pupils.

The author presents a model of psychological well-being of senior pupils and a conceptual model of the impact of social Internet practices on the psychological wellbeing of senior pupils, which takes into account the content of practices, situational and targeted self-regulation of their realization.

An empirical study of the impact of social Internet practices on the psychological well-being of senior pupils is carried out. The general sample consisted of $9^{\text {th- }} 11^{\text {th }}$ grade pupils of secondary schools, a total of 1,144 respondents, including 458 boys and 686 girls, aged 14 to 17 . The study used: author's methods of express evaluation of psychological well-being, assessment of the content of social Internet practices, separate scales of the questionnaire for assessing the level of media culture (L. Naydonova, O. Baryshpolets, etc.), author's questionnaire of subjective selfassessment of impact of social Internet-practices on psychological well-being.

The results of the empirical study have revealed the phenomenon of asymmetry of subjective assessments of the impact of social Internet practices: senior pupils overestimate the positivity of the impact of the Internet. Besides, the higher the level of real psychological well-being of respondents, the more their subjective assessments of the impact of Internet practices are shifted towards the positive, i.e. they more positively perceive any activity on the Internet, although it may objectively cause certain risks.

Peculiarities of psychological well-being of active and inactive users of various social Internet practices are identified and described. The positive impact of the practices of searching for interesting information and information for learning (informational consumer practices), as well as the practice of using social networks to maintain friendly relations (communicative) on psychological well-being have been confirmed. It has been established that computer games and surfing the web without a purpose have a negative impact on the psychological well-being of senior pupils.

An analysis of the differences between situational and targeted self-regulation of senior pupil's practices with different levels of psychological well-being is presented. Senior pupils with a high level of psychological well-being are better able to voluntarily self-regulate social Internet practices. It has been established that the goals of Internet use aimed at development (to search for educational information, skills
\end{abstract}


development, reading news) and maintaining friendly relations have a positive impact on psychological well-being, while the use of the Internet without a clear purpose and to earn money has a negative impact.

Keywords: psychological well-being, social internet practices, senior pupils, Internet, self-regulation

\section{Introduction}

At the present stage of historical development there is a transition to the information society, which is characterised by the increasing impact of information and communication technologies on all spheres of human life. The active spread of the Internet is accompanied by the emergence of new social practices that transform habitual priorities and behavioural standards, change established patterns of activity, and thus have the potential to affect human well-being in the information society.

Different aspects of psychological well-being (PWB) are the object of study of domestic researchers (Alexandrov, 2010; Hrub'yak, 2017; Tytarenko, 2016;), foreign scholars (Argyle, 2003; Boniwell, 2009; Deci, Ryan, 2001; Waterman, 2004;), scholars from the post-Soviet countries (Voronina, 2002; Sozontov, 2006; Shevelenkova, Fesenko, 2005; Shiryaeva, 2008). However, despite a large number of studies aimed at elucidating the impact of social factors on psychological well-being (level of income, education, marital status, etc.), the features of the transformation of psychological well-being under the influence of the latest media remain insufficiently studied.

Social Internet practices (SIP), as an activity that has a routine nature and consists of habitual, repetitive actions associated with the use of the network to solve problems or increase efficiency in various spheres of life (Radkevych, 2009), significantly expand a person's opportunities in the professional sphere, communication, leisure. At the same time, such virtual practices are a relatively new phenomenon of social reality, so there is an urgent need to classify, determine its parameters and characteristics, clarify the impact of various social Internet practices on the psychological well-being of studying youth, including senior pupils.

Research objective: determine the content and self-regulatory components of senior pupils' implementation of social Internet practices as a factor of general psychological well-being, and its individual components.

\section{Theoretical background}

The need for a category that would denote the external and internal positive functioning of man has existed since ancient times. Philosophy, and later psychology studied various aspects of this phenomenon through the categories of "happiness", "pleasure", "well-being". In 1969, N. Bradburn's book The Structure of Psychological Well-Being was published, which first used the term "psychological well-being" (Bradburn, 1969). The current state of development of felicitary issues suggests that despite significant achievements in the study of this topic, there is an urgent need for a clear definition of the concept of "psychological well-being", because there is currently no generally accepted definition of this term.

Generalized analysis allows identifying three main approaches to the study of psychological well-being. The first, hedonistic approach, identifies PWB with a subjective sense of happiness, life 
satisfaction (Bradburn, 1969; Argyle, 2003; Caprara et al. 2006). The second approach is eudemonistic, considering PWB as a process of realization of personal potential (Deci, Ryan, 2001; Waterman, 2004 and others). Within this approach, the concept of psychological well-being proposed by K. Ryff (1995) requires special attention. Based on the analysis of the works of A. Maslow, C. Rogers, G. Allport, C.-G. Jung, E. Eixon, S. Buhler, M. Jahoda, K. Ryff proposed a model of psychological well-being, which contains the following components: Self Acceptance (a positive attitude to oneself despite the awareness of one's own shortcomings and limitations), Positive Relations With Others (the ability to maintain close relationships with others based on support and empathy), Environmental Mastery (ability to meet the requirements of the environment, to plan and effectively carry out the planned, to overcome difficulties), Purpose in Life (the ability to find meaning in one's own efforts and life challenges, to experience the meaning of one's own existence), Autonomy (ability to build one's own lives according to one's own beliefs, the ability to organize one's own environment according to one's own needs and desires), Personal Growth (the desire to realize one's own abilities and talents, openness to new experiences). Thus, psychological well-being is seen as the conformity of one's life to a certain positive social norm.

The third approach is integrative. In the context of this approach, PWB is considered taking into account its hedonistic and eudemonistic aspects (Nosenko, Arshava, 2009; Shiryaeva, 2008; Voronina, 2005; Oleksandrov, 2010). Among the attempts to combine hedonistic and eudemonistic approaches are the developments of P. P. Fesenko and T.D. Shevelenkova (2005), which, based on the theory of K. Ryff, consider psychological well-being as an integrative indicator of a person's focus on the realization of this need, which is subjectively expressed in a sense of happiness, satisfaction with oneself and one's own life." The authors of the theory emphasize both the subjective assessment of one's own life and the realization of the positive functioning of the individual.

Our understanding of the essence of the concept of psychological well-being is also based on the provisions of K. Ryff's theory. This concept is one of the most theoretically sound approaches to determining psychological well-being, it is widely used in modern scientific research by foreign and domestic authors. In our opinion, the components of psychological well-being proposed by K. Ryff can be further structured.

The classic of domestic science V.N. Miasishchev presented the idea of reducing all the diversity of personal relationships with the surrounding reality to certain interconnected groups (Miasishchev, 1998). According to the concept of this scholar, we can distinguish 3 levels of personality-environment interaction: intrapersonal (relations of the "self -- other self" level), interpersonal (relations of the "self - other person" level), and relations with the environment ("self - environment" level).

In our opinion, the components of psychological well-being proposed by $\mathrm{K}$. Ryff can be divided into 3 vectors taking into account these levels. Personality vector «Self-attitude» (covers such parameters as "personal growth" and "self-acceptance"), vector of interaction with other people «Attitude to others» (consists of such parameters as 
"autonomy" and "positive relationships with others"), and activity vector «Attitude to environment» (covers parameters of "environmental mastery" and "goals in life") (Figure 1).

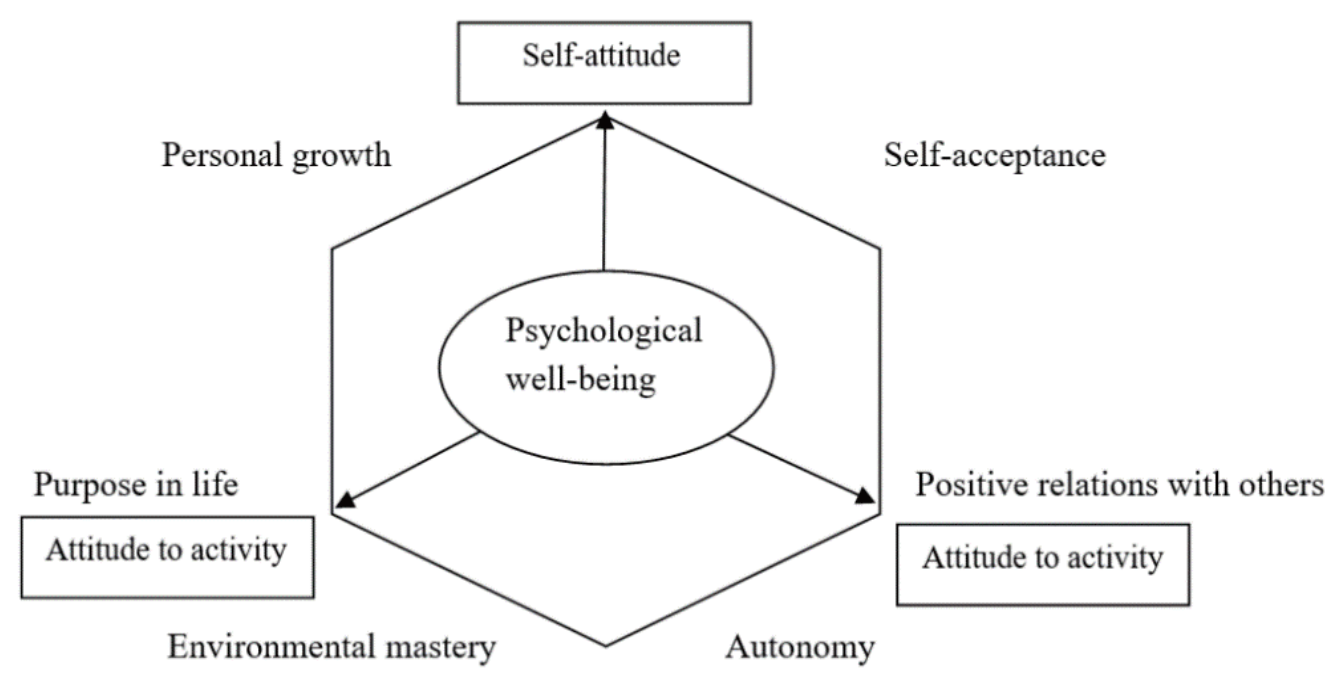

Fig.1. Model of the structure of the psychological well-being concept

Analysis of research on the phenomenon of social practices details the definition of the term "social Internet practices" (Radkevych, 2009), as a routine activity consisting of habitual, repetitive actions, which are associated with using the network to solve problems or improve efficiency in various spheres of life, as well as to meet various needs.

Based on the analysis of existing approaches to the characterization of social practices realized in the Internet environment (Radkevych, 2009; Malieieva, 2014; Halich, 2010; Reutov, 2015; Khmil, 2015; Li and Bernoff, 2010), a psychological classification of SIP by activity content is proposed. According to this classification, various types of network activity of senior pupils are divided into "creative", "critical", "classification", "communicative" and "consumer".

The relevant approach to the consideration of social Internet practices is based on the concept of "socio- technographic ladder" proposed by Forrester analysts Charlene Li and John Bernoff (2008), which was developed to describe and analyse the processes of interaction and communication in the network.

The principle of building this classification is the grouping of users according to their usual ways of spending time on the Internet. The authors of the classification identified six types of users: "creators" (create and publish new content), "critics" (express their attitude to the content already created and published), "collectors" (classify and arrange content on the Internet in different ways), "communicators" (use social networking websites), "consumers" (consume content - listen/watch audio and video, read forums, visit advertisers' websites), and "inactive" (do not use any of the above practices on the network).

According to the change in the object of classification, we reformulated the 
names of groups (e.g. "Creators" in "Creative Practices"); expanded the list of operational features guiding assignment to a particular group; removed the group of "inactive", because it indicates the absence of practice in the reformulated version.

To clarify the hypothesis about the impact of the content of SIPs on the PWB of senior pupils, we have distributed them according to the level of knowledge that is expected to be applied when using a particular practice. Thus, we can distinguish practices of the highest level of knowledge (mental skills according to Bloom's taxonomy): creative, critical, classificational. According to our assumption, such practices that require a higher level of mental skills for their implementation should provide a developmental effect and contribute to improving the psychological well-being of senior pupils.

It is important to take into account the content but there is insufficient basis for constructing the classification of SIPs in the context of their impact on PWB.

In our opinion, the PWB of users can be related to Internet practices at the level of whether they are a tool for the development of studying youth, or are used to compensate for existing deficits, in particular to distract from real problems.

To test this part of the hypothesis, it is necessary to consider the selfregulatory component of the realization of social Internet practices, which has two components: targeted and situational selfregulation.

Targeted self-regulation provides an understanding of how clearly the user determines the purpose of being on the Internet, whether he acts automatically or following the example of others; if the goal is set consciously, what it is then. We can assume that the clearer the goal is the more it correlates with those development tasks that are relevant at a certain stage of life, the better for PWB. The more blurred the goal, and the more it aims to correct symptoms (such as distraction from problems, escape from reality), the worse for psychological well-being.

Situational self-regulation helps to understand how the user behaves while being directly in a situation of using practice. One aspect is the time spent online. The results of empirical studies show that taking this factor into account it is very important for understanding the impact of SIPs. It is noted that the impact of time spent online is nonlinear, and moderate involvement in SIP is not only not harmful, but even improves user PWB (Twenge \& Campbell, 2019), while excessive daily use ( 5 or more hours per day) has negative consequences (Poulain et. al, 2018). We also attribute the ability to create a plan to stay online and implement it (in particular, without being distracted by irrelevant content or too immersed in the media environment) to the aspects of situational self-regulation. In our opinion, the more the user manages to implement the planned, the more positively it is reflected on PWB, and vice versa - procrastination in the network has a negative impact, as evidenced by large empirical studies (Reinecke, Meier et al., 2016).

In our opinion, it is also important to take into account how the subject assesses the impact of practice on the actual PWB (Naydonov, Naydonova, Hryhorovska, 2017). Subjective self-assessment of the impact of practices can be a driving force in changing one's own habits of using the network, or, conversely, consolidate them. 
In our opinion, the complex model should take into account both the content of practices and self-regulatory aspects of their realization, as well as the subjective assessment of practices. A schematic representation of this model is presented in Figure 2.

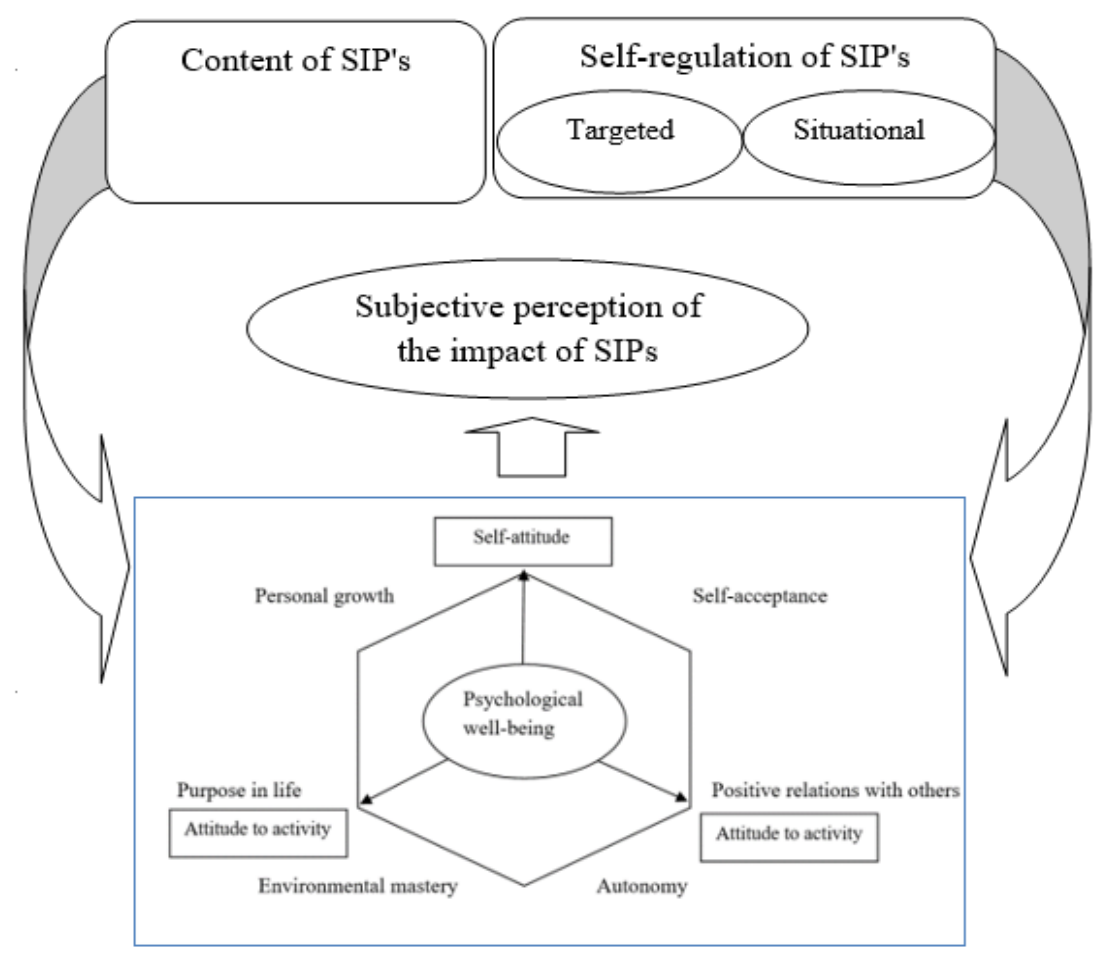

Fig. 2. A comprehensive conceptual model of the impact of SIP on the psychological well-being of senior pupils

\section{Methodology}

Sample. The general sample consisted of $9^{\text {th- }} 11^{\text {th }}$ grade students of secondary schools of 7 regions (Lviv, Dnipropetrovsk, Zaporizhzhia, Cherkasy, Ivano-Frankivsk, Mykolaiv and Poltava). A total of 1,144 respondents took part in the survey, including 458 boys and 686 girls. The age of the survey participants was from 14 to 17 years (average age 15.56, median - 16).

Methods. General theoretical methods: analysis, synthesis, comparison, systematization and generalization. Psychodiagnostic methods: to determine the level of psychological well-being author's Ukrainian-language adaptation of K. Ryff's method and standardized author's method of express evaluation of PWB; to study the features of social Internet practices of senior pupils author's method of assessing the content of SIP, separate scales of the questionnaire for assessing the level of media culture (L.A. Naydonova, O.T. Baryshpolets, etc.), the author's questionnaire for self-assessment of the impact of SIP on psychological wellbeing. For the analysis of the obtained data we used mathematical and statistical analysis of data: Cronbach's $\alpha$, Pearson's $\mathrm{X}^{2}$, Student's t-test for the evaluation of independent samples, analysis of variance (one-way ANOVA), correlation analysis (SPSS version 19.0). 


\section{Results}

To analyse the self-assessment of the impact of SIPs on PWB, the responses of the survey participants have been divided into groups according to the general indicators according to the PWB express evaluation questionnaire into 3 groups: with low (310 respondents), medium (560 people) and high (274 respondents) indicators. Pearson's chi-square test has been used to statistically confirm the differences in the results obtained.

It has been established that senior pupils tend to evaluate the impact of their activities on the Internet on various PWB parameters as neutral or positive. The higher the PWB of respondents, the more positively they assess the impact of their Internet practices on certain parameters of their own PWB, and vice versa. To a large extent, a similar trend concerns the assessment of the impact of SIPs on such a component of PWB as personal growth.

We can state that at the level of subjective perception most of the survey participants do not see the risks in the impact of their own activities on the Internet on their psychological wellbeing.

When analysing the differences in the profiles of psychological well-being of senior pupils depending on the frequency of use of various SIPs, we revealed the general activity of senior pupils using certain types of SIPs. It has been found that the most popular practices among senior pupils are those belonging to two types according to the author's classification: communicative $(80.33 \%$ of participants use social networks daily or almost daily) and consumer (76.77\% constantly look for information to study; $74.39 \%$ search for information on topics of interest, $56.56 \%$ search and view audio and video information).
For each of the practices, a comparison has been made between respondents who are its regular users and those who use it very rarely or never use it (Table 2). To compare the performance of active and inactive users, the Student's t-test has been used for independent samples, upon having compared the variances of the samples under consideration using the Levene's test.

It has been established that the most sensitive component of PWB that responds to Internet practices there is a Personal Growth. Feelings of personal change, tracking the maturation of one's own views, a focus on change in one's own life, and a willingness to accept new experiences that are integrated into this component have a negative significant relationship with the vast majority of practices.

It has been found that Internet practices requiring a higher level of knowledge (creative, critical, classification) cannot be unambiguously considered as contributing to the psychological well-being of senior pupils. Creative and critical practices have a negative relationship with the individual components of PWB and its overall level. In case of the active use of such classificational practice as Collection and Classification of Information on Your Page, we recorded a combinatorial type of communication - positive with such a component as Autonomy, and negative with the general level of PWB, Selfacceptance, Personal Growth, Environmental Mastery and Purpose in Life.

Communicative and consumer practices are heterogeneous in their impact on PWB. Among the communicative practices, we can distinguish communicative-supportive 
ones (use of social networks), which are interesting information and search for positively related to PWB, and information for learning), which are communicative-compensatory (search for positively related to PWB, and risky (use new friends), which are negatively related of the Internet without a purpose and to this parameter. Among consumer playing computer games), which practices, there are also two types: negatively related to both the general level information-pragmatic (search for of PWB and all its components.

Table 2. Significant differences in PWB rates between users who actively practice certain types of SIPs and those who do not

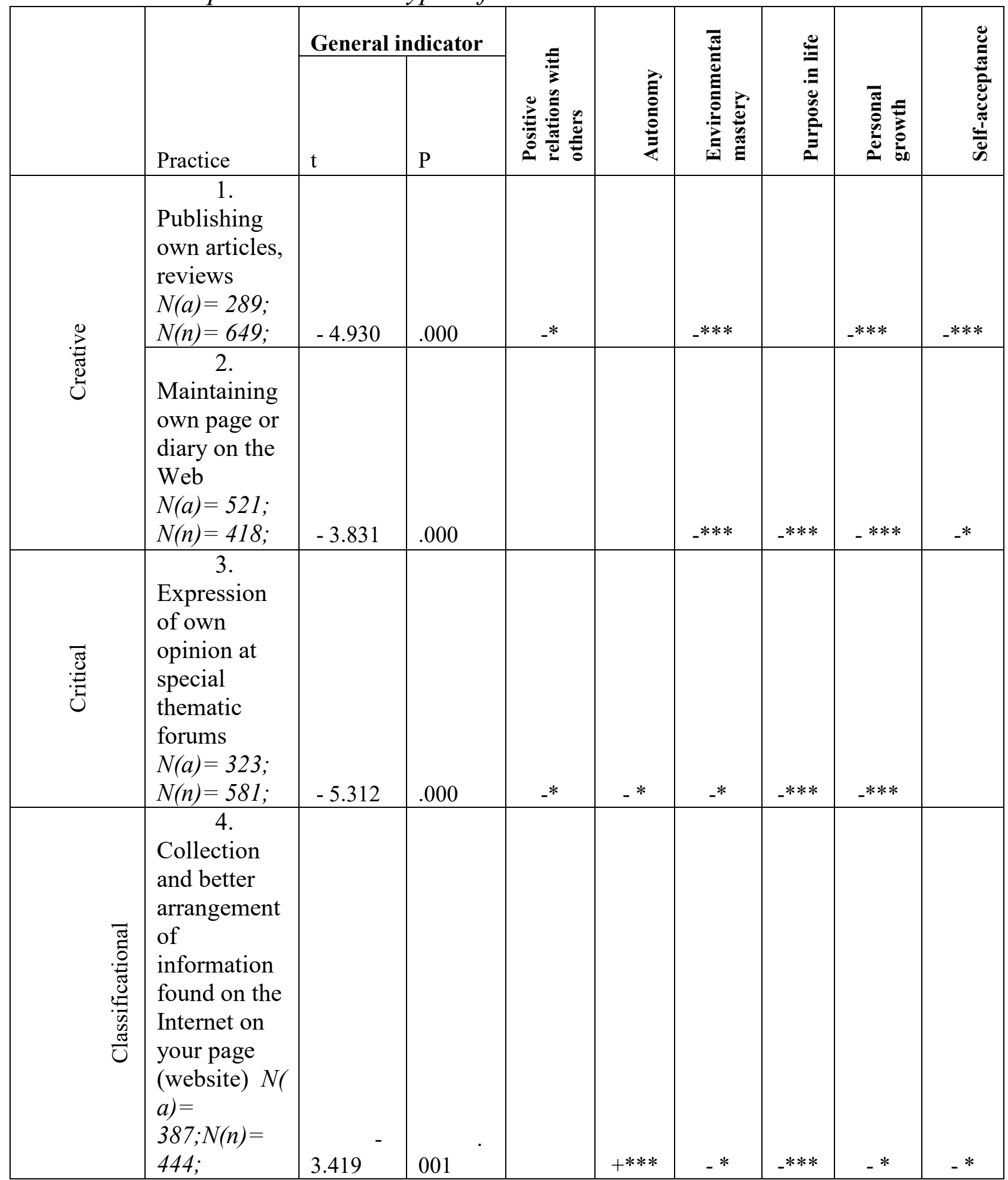




\begin{tabular}{|c|c|c|c|c|c|c|c|c|c|}
\hline \multirow{2}{*}{ 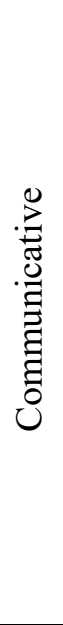 } & $\begin{array}{l}\quad 5 . \\
\text { Search for } \\
\text { friends, new } \\
\text { acquaintance } \\
\mathrm{s} \\
N(a)= \\
438 ; N(n)= \\
433 ;\end{array}$ & $3.296^{-}$ & 001 & & _** & & $-* *$ & $-* * *$ & \\
\hline & $\begin{array}{l}\quad 6 . \text { Use } \\
\text { of social } \\
\text { networks } \\
N(a)=849 ; \\
N(n)=163 ;\end{array}$ & $396^{3}$ & 001 & $+* * *$ & & $+*$ & $+* *$ & $+* * *$ & \\
\hline \multirow{4}{*}{ 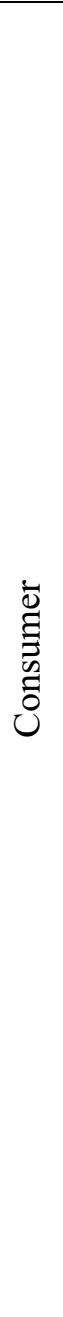 } & \begin{tabular}{l}
\multicolumn{1}{c}{7.} \\
Pointless \\
surfing the \\
web \\
$\qquad N(a)=$ \\
$529 ; N(n)=$ \\
$363 ;$
\end{tabular} & 8.812 & 000 & $-* * *$ & $-* * *$ & $-* * *$ & $-* * *$ & $-* * *$ & $-* * *$ \\
\hline & $\begin{array}{l}\quad 8 . \\
\text { Online } \\
\text { computer } \\
\text { games } \\
\qquad N(a)= \\
427 ; N(n)= \\
529 ;\end{array}$ & -7.666 & -.000 & $-* * *$ & $-* * *$ & $-* * *$ & $-* * *$ & $-* * *$ & $-* * *$ \\
\hline & $\begin{array}{l}\quad 9 . \\
\text { Search for } \\
\text { information } \\
\text { on topics of } \\
\text { interest } \\
N(a)=791 ; N \\
(n)=161 ;\end{array}$ & 5.261 & -.000 & $+* * *$ & & $+* * *$ & $+* * *$ & $+* * *$ & $+* * *$ \\
\hline & $\begin{array}{l}\quad 10 \text {. } \\
\text { Search for } \\
\text { information } \\
\text { for learning } \\
N(a)=877 \text {; } \\
N(n)=84\end{array}$ & 3.298 & 001 & $+* *$ & $+*$ & ${ }^{+}+$ & $+* *$ & $+* *$ & \\
\hline
\end{tabular}

Conventions: N(a) - the number of active users of the practice; N(n) - the number of inactive users of the practice; "+" average PWB profiles of active users, which significantly outweigh inactive ones; "-" average PWB profiles of active users are significantly lower than inactive ones; - * $\mathrm{p} \leq 0.05$, $* * \mathrm{p} \leq 0.01, * * * \mathrm{p} \leq 0.001$

Thus, we improved the classification of SIPs according to the results of the analysis of empirical data. We identified two types of consumer practices: information-pragmatic (search for interesting information and search for information for learning) and risky (use of the Internet without a purpose and computer games). 
We used the analysis of variance, namely - one-factor ANOVA - to better understand the results obtained in terms of the direction of correlation, to test the hypothesis of the impact of the use of Internet practices on PWB of senior pupils. The independent variable (factor) is the frequency of practice, measured by an ordinal scale (5 gradations). The dependent variable is PWB, for the correctness of the method the indicators have been converted from the Likert scale to the dichotomous one. Levene's test has been used to preliminarily check the groups for the homogeneity of the variances. To determine the significance of differences in the mean values of the groups after the deviation of $\mathrm{H} 0$, we used the Scheffe's test. In those cases when the condition of equality of variances was violated, we used the Brown and Forsythe F-test of equal variances, and reliability of differences of group means was determined by using Danett's method.

A direct relationship between the frequency of use of such SIPs as Search for Interesting Information in the Web $(\mathrm{F}$ $=12.286 \mathrm{p} \leq 0.000$ ) and Search for

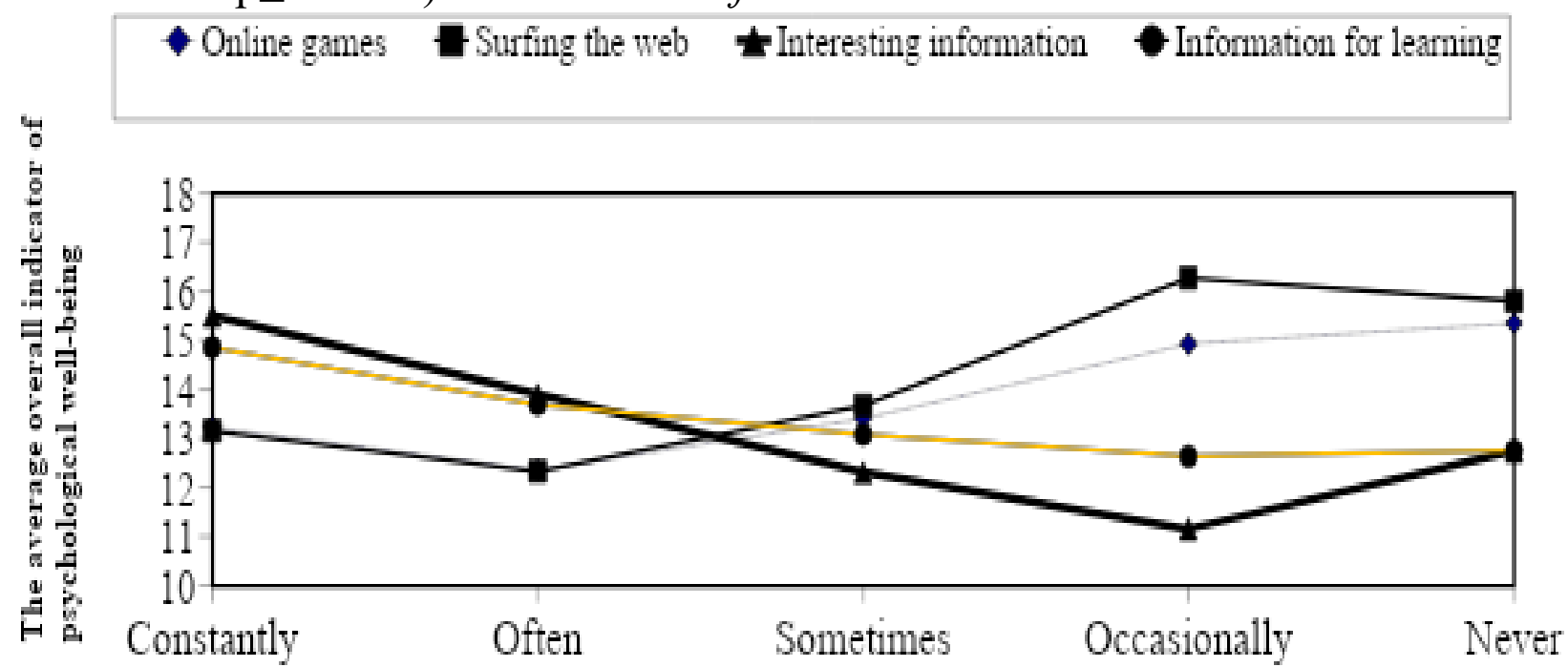

Fig. 3. Graph of the average values of the factor effect on psychological wellbeing at different gradations of the intensity of practices
Information for Learning (3.855 $\mathrm{p} \leq$ 0.004 ) and the level of PWB of senior pupils has statistically been confirmed. According to the data obtained, an increase in the frequency of use of these practices leads to a directly proportional increase in PWB rates. The frequency of use of such practices as Computer Games (the Brown and Forsythe F-test of equal variances $8.831 \mathrm{p} \leq 0.000)$ and Pointless Surfing the Web (Brown-Forsythe F-test $=$ $14.472 p \leq 0.000$ ) has an inverse effect on the level of PWB. Intensification of the use of these types of practices leads to a decrease in the overall level of PWB (see Figure 3).

Other types of practices do not have a direct linear relationship with PWB (search for friends and new acquaintances, collection and arrangement of information, some critical and creative practices). Some of them have no significant impact on PWB (search for media files, commenting on news on the Internet). 
Among the situational selfregulatory aspects of social Internet practices, we have identified the time spent online and self-regulation of the duration of stay online; volitional selfregulation, which is manifested in the tendency to hold attention and not be distracted by irrelevant content, searching for information on the Internet, as well as in the decision not to change plans for the web under the influence of others; programming of social Internet practices, which consists in making a program of one's own stay on the Internet and evaluation of its implementation; immersion in web practices.

All the above parameters have been investigated using the questions of the scale of assessment of situational selfregulation of SIPs in respondents from groups with different levels of PWB. Pearson's chi-square test has been used to statistically confirm the differences. The Spearman correlation coefficient has been used to determine the correlation between individual indicators of SIP selfregulation and structural components of PWB.

We have found a number of differences in situational self-regulation of SIPs in senior pupils with different levels of PWB.

Senior pupils with a high level of PWB are better at voluntary selfregulation and SIP programming: they're less distracted by irrelevant content when searching for the necessary information, less likely to change their web plans under the influence of online peers, less likely to make a program of their own online stay, but better fulfil the plans.
Senior pupils with low PWB levels are relatively more likely than their peers to immerse themselves in the virtual world (characterized by excessive propensity to stream states in the network, a sense of emptiness and boredom in the absence of Internet access, perception of the network as the only place for communication and activities opposite to reality). Among senior pupils with a low level of PWB, we have found relatively more "heavy Internet users" than among representatives of other groups.

The study of targeted self-regulation of practices has been conducted in 2 stages: the 1st stage provided for the analysis of the frequency of choice of certain purposes of Internet use by senior pupils from different levels of PWB groups and the identification of significant differences between them. Pearson's chi-square criterion has been used to confirm the validity of the obtained differences. At the 2nd stage, we have tested the hypothesis concerning the correctness of considering certain purposes of Internet use as factors influencing the PWB of senior pupils for a deeper understanding of the obtained differences. We have determined the relationship between the structural components of PWB and Internet use by the Spearman's correlation coefficient.

According to the results of the 1 st stage, we have identified 2 types of statistically confirmed differences. We have proved that senior pupils with a proper level of psychological well-being are more likely to use the Internet to find educational information, to develop their 
skills, to read the news and to maintain friendly relations.

Senior pupils who have a low level of PWB are more likely to be unaware of their purpose in using the Internet (guided by habit, or influenced by others in choosing their own Internet practices), more actively use the network to respond to certain negative states (namely, to reduce aggression and relax, to forget and distract from problems, for pleasure), and are more likely to find like-minded people on the Internet than their peers having a proper level of psychological well-being.

We have confirmed significant relationships by analysis of variance (oneway ANOVA). The procedure has been performed according to a scheme similar to the scheme of content analysis of social Internet practices, which was described above.

The results of the analysis of variance confirmed the hypothesis of a positive impact on PWB of those goals of Internet use that are related to the personal development of senior pupils (Using the Internet to Find Information for Learning,

\section{Discussion}

Our study proves that at the level of subjective perception, most senior pupils do not see the risks in the impact of their activities on the Internet on their psychological well-being, which raises the issue of preventive and educational work with them.

The main direction of strengthening psychological well-being under the influence of SIPs is the principle of targeted self-regulation: the more the purpose of using the Internet meets the goals of pupils' development and the
To Train Skills, To Read the Latest News). It has been established that the purpose of using the Internet to Maintain Friendly Relations, Communication is also a factor in improving the PWB of senior pupils. It has been statistically confirmed that the lack of a clear understanding of the purpose of using the Internet (Usage by Habit, Because Others Use), as well as the use of the network To Gorget, Distract from Problems are factors that worsen PWB of senior pupils. In our opinion, this is due to distractions from solving current problems, and due to a decrease in the sense of subjectivity. We have found that goals aimed at solving current problems, in particular through making money and reacting emotionally by reducing aggression and relaxation, are also negatively related to PWD and can be seen as negative factors.

Based on these data, it has been concluded that the more the purpose of using the Internet meets the goals of human development and the more accurately it is formulated, the more it contributes to improving the PWB of senior pupils.

more accurately it is formulated, the more it improves PWB of senior pupils.

We see the prospects for further research in the detailed development of a set of methods to increase the level of PWB of the younger generation by improving their media culture and through the rational organization of SIPs. Particular priority is the development of such a complex for junior pupils in connection with the trend of using most SIPs at increasingly earlier age, and the growing share of distance learning. 


\section{Conclusion}

Social Internet practices of senior pupils are classified according to the content of activities into such categories as "creative", "classificational", "social" and "consumer", the latter are divided into information-pragmatic and risky (positive and negative, respectively) according to the criteria of their impact on the psychological well-being of senior pupils.

Senior pupils tend to overestimate the positive impact of SIPs on their psychological well-being: there is a tendency to assess the impact of their online activities as positive or neutral, while the analysis of empirical data shows that there is also a negative impact - both from individual practices in terms of content and with a lack of self-regulatory components. In addition, the higher the level of real psychological well-being of respondents, the more their subjective assessments of the impact of Internet practices shift to the positive, i.e. the more positively they perceive any activity on the Internet, although it may objectively cause certain risks. This phenomenon is called the asymmetry of subjective assessments of the impact of SIPs on psychological well-being.

It has been established that Internet practices have different impact on PWB depending on their content. It is statistically confirmed that the following SIPs have a positive effect on the PWB of senior pupils: search for interesting information and information for learning (information-pragmatic

consumer practices), use of social networks to maintain friendly relations (communicative practice). Instead, using the Internet without a purpose and playing computer games are risky consumer practices that have a negative impact on PWB.

It has been established that excessive enthusiasm for creative and critical practices has a negative relationship with certain components of PWB of senior pupils and its overall level. Classificational SIPs have a multidirectional relationship: the collection and arrangement of information has a positive effect on autonomy, and negatively affects other components of the PWB. Thus, the hypothesis that SIPs of the higher level of knowledge (creative, critical, classificational) contribute to the PWB of senior pupils is refuted, as the direct positive influence has not been confirmed.

The goals of using the Internet, which are related to the personal development of senior pupils (use for the purpose of learning, training skills, and orientation in the information space through news tracking) have a positive impact on PWB. Using the Internet without a clear purpose (surfing), as well as using the network for escapism (to escape) have a negative impact. Goals aimed at solving current problems, in particular through making money and reacting emotionally by reducing aggression and relaxation, have also been found to be negatively related to PWD and can be seen as factors in the negative impact of the Internet on senior pupils.

Conflict of interests: We claim that there is no conflict of scientific interest.

\section{References}

Alexandrov, Y. M. (2010) PhD dissertation. Samorehuliatsiia yak chynnyk psykholohichnoho blahopoluchchia stkdentskoi molodi [Self-Regulation as a Factor of Student Youth Psychological Well- 
being]. V. N. Karazin Kharkiv National University. [in Ukrainian]. Argyle, M. (2013) The psychology of happiness. Routledge.

Boniwell, I. (2009) Klyuchi k

blagopoluchiyu [Keys to wellbeing]. Moscow: Vremya. [in Russian].

Bradburn, N. (1969) The Structure of

Psychological Well-Being. Chicago:

Aldine Pub. Co.

Caprara, G., Steca, P., Gerbino, M., Paciello, M., \& Vecchio, G. (2006). Looking for adolescents' well-being: Self-efficacy beliefs as determinants of positive thinking and happiness. Epidemiologia E Psichiatria Sociale, 15(1), 30-43. https://doi.org/10.1017/S1121189X 00002013

Halich, T. O. (2010) Priorytetnist osvitnikh ta komunikatsiinykh praktyk vykorystannia studentamy merezhi Internet. (Priority of educational and communicative practices of Internet users among the students). Visnyk Kharkivskoho natsionalnoho universytetu imeni $V$. N. Karazina. 891, 188-191. [in Ukrainian].

Hrub'yak, O. (2017). Psihologicheskoe blagopoluchie sovremennyih muzhchin i zhenschin perioda ranney vzroslosti. [Psychological well-being of modern men and women in early adulthood] Psychological journal, 3(1), 198207. [in Russian].

Khmil, Ya.V. (2015) Vydove riznomanittia internet-praktyk ukrainskykh studentiv. [Diversity of internet practices of the ukrainian students] Hrani. 12/1, 100-103. [in Ukrainian].
Li, C., Bernoff, J. (2008) Groundswell: Winning in a World Transformed by Social Technologies. Harvard Business Press.

Malieieva, N. S. (2014) Sotsialnopsykholohichnyi zmist komunikatyvnykh praktyk u merezhi internet [Psychosocial content of communicative practices on the internet]. Nauka i osvita. 11, 113118. [in Ukrainian].

Miasishchev, V. N. (1998). Psikhologiia otnoshenii.

Izbrannye psikhologicheskie trudy. [in Russian].

Naydonov, M. I., Naydonova, L. A., Hryhorovska, L. V. (2017) Svidoma i systemna samorehuliatsiia subiektiv sotsializatsii: hruprefleksyvnyi pidkhid. [Conscious and systemic self-regulation of the subjects of socialization: groupreflexive approach] International Journal of Education \& Development. Volume 3 . Psychology / Taras Shevchenko National University of Kyiv, Ukrainian Association of Educational and Developmental Psychology. Co-publ.: Publishing office: Accent Graphics Communications. Hamilton ON, 2537.

Nosenko, E. L., Arshava, I. F. (2009) Shliakhy nablyzhennia predmetu psykholohichnoho doslidzhennia do yoho obiektu (na prykladi vyvchennia aktyvnosti osobystosti) [Ways of approaching the subject of psychological research to its object (on the example of studying the activity of the individual)]. Aktualni problemy psykholohii: zb. nauk.pr. in-tu psykholohii im. H.S. Kostiuka APN Ukrainy. Ekolohichna 
psykholohiia.Vol.7(19), 149-154. [in Ukrainian].

Poulain, T., Vogel, M., Ludwig, J., Grafe, N., Körner, A., \& Kiess, W. (2018) Reciprocal longitudinal associations between adolescents' media consumption and psychological health. Academic Pediatrics. Academic Pediatrics, Volume 19, Issue 1, 109 - 117. https://doi.org/10.1016/j.acap.201 8.08.009

Radkevich, A. L. (2009) Sotsialnyie internet-praktiki kak ob'ekt sotsiologicheskogo analiza [Internetbased Social Practices as a Subject of Sociological Analysis]. Informatsionnyiy gumanitarnyiy portal Znanie. Ponimanie. Umenie, (3), 10-10.

Reinecke, L., Meier, A., Aufenanger, S., Beutel, M. E., Dreier, M., Quiring, O., Müller, K. W. (2018). Permanently online and permanently procrastinating? The mediating role of Internet use for the effects of trait procrastination on psychological health and well-being. New Media \& Society, 20(3), 862-880. https://doi.org/10.1177/146144481 6675437

Reutov, E. (2015) Internet-praktiki i informatsionnoe predpochtenie naseleniya. Sotsis. [Internet practices and preferences of the population]. 4, 140-148. [in Russian].

Ryan, R. M., Deci, E. L. (2001) On happiness and human potentials: a review of research on hedonic and eudaimonic well-being. Annual Review of Psychology. V. 52, 141166.

Ryff, C. D. \& Keyes, C. L. M. (1995) The Structure of Psychological WellBeing Revisited. Journal of
Personality and Social Psychology. 69(4), 719-727.

Shevelenkova, T. D., \& Fesenko, P. P. (2005).

Psihologicheskoe blagopoluchie lichnosti (obzor osnovnyih kontseptsiy i metodika issledovaniya) [Psychological wellbeing of the individual (an overview of the main concepts and research methodology]. Psihologicheskaya diagnostika, 3, 95-129. [in Russian]. Shiryaeva, O. S. (2008) PhD dissertation. Psihologicheskoe blagopoluchie lichnosti $\mathrm{v}$ ekstrimalnyih usloviyah zhiznideyatelnosti [Psychological well-being of the individual in extreme living conditions]. Federal State Budgetary Educational Institution of Higher Education "Kamchatka State University named after Vitus Bering"[in Russian].

Sozontov, A. (2006) Gedonisticheskiy i evdemonisticheskiy podhodyi $\mathrm{k}$ probleme psihologicheskogo blagopoluchiya. [Hedonistic and eudemonistic approaches to the question of psychological wellbeing.] Voprosyi psihologii. 4, 105114. [in Russian].

Twenge, J. M., \& Campbell W. K. (2019) Media Use Is Linked to Lower Psychological Well-Being: Evidence from Three Datasets. Psychiatric Quarterly. 90, 311-331. https://doi.org/10.1007/s11126019-09630-7

Tytarenko, T. M. (2016) Indykatory psykholohichnoho zdorovia osobystosti. psychological health indicators.] Psykholohichni nauky: problemy $i$ zdobutky. 9,196-215. [in Ukrainian].

Voronina, A. V. (2005). Problema psihicheskogo zdorovya i 
blagopoluchiya cheloveka: obzor kontseptsiy i opyit strukturnourovnevogo analiza [The problem of mental health and human wellbeing. Concepts overview and experience of level-structure analysis]. Sibirskiy psihologicheskiy zhurnal, (21), 142147. [in Russian].

Waterman, A. S. (2004) Finding someone to be: studies on the role of intrinsic motivation in identity formation. Identity: an international journal of theory and reseach. 4(3), $209-228$. 